Jerusalem Papers in Regulation \& Governance

Working Paper No. 50

February 2013

\title{
LAW AND DEVELOPMENT IN
}

CENTRAL AND EASTERN EUROPE: NEOLIBERAL DEVELOPMENTAL STATE AND ITS PROBLEMS

\section{Bojan Bugaric}

Professor of Law, Faculty of Law,

University of Ljubljana,

Ljubljana, Slovenia, 1000

E-Mail: bojan.bugaric@pf.uni-lj.si

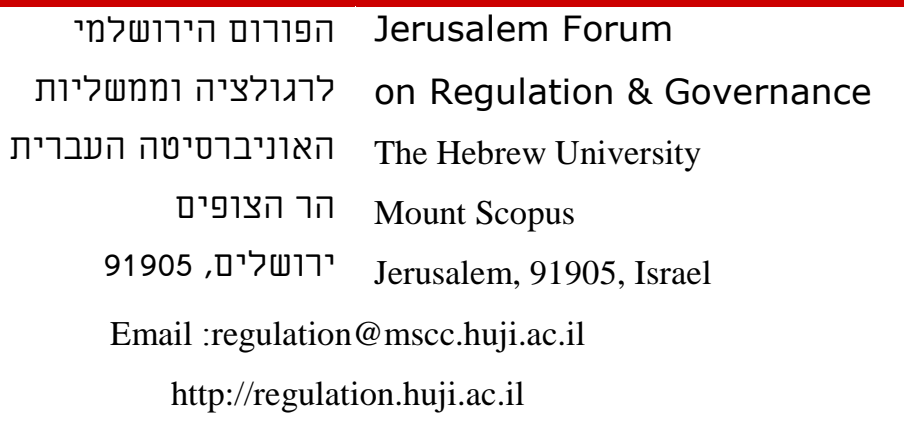




\section{Law and Development in Central and Eastern Europe: Neoliberal Developmental State and Its Problems}

\section{Bojan Bugaric}

Abstract: In the first part of the article, I describe the origins of neoliberal developmental states in CEE. I start with the outline of administrative reforms during the age of the Washington consensus and examine how the neo-liberal legal policies and theories affected the administrative structures built in that period. I try to show that under the influence of the neoliberal "rule of law" model CEE developed a distinct, neoliberal developmental state. During the early stage of administrative reforms, they followed a one-size-fits-all approach and hastened to transplant various Western-style administrative structures without paying sufficient attention to social context and disregarding the policy relevance of such rules. I use the example of civil service reforms because they were at the epicenter of the first stage of administrative reforms. In the second part of the article, I discuss the EU-inspired innovation development policies, which gradually emerged as a major albeit truncated version of developmental policy in CEE. But then again, the inadequacy of the administrative structures built during the early stage of transition turned out to be one of the key inhibiting factors that prevented these new development policies from succeeding. However, as the Strategy for Poland, the only alternative development strategy to the Washington consensus in the region shows, selection of adequate economic policies is as important as the creation of adequate legal and political institutions. Poland achieved remarkable economic results with institutions which were considered to be inadequate by actors like the EU, the World Bank and IMF. I conclude with general observations about the importance of CEE examples for development policies of other middle-income countries (MICs) in the region.

Key words: Law and development, Central and Eastern Europe, rule of law, neoliberal developmental state, new institutional economics, post-Washington consensus

Acknowledgment: I have benefited from commentary and advice on earlier drafts from Ivan T. Berend, Diane Desierto, Tom Ginsburg, Grzegorz Kolodko, Martin Krygier, Randy Peerenboom and other participants of the conference "Law and Economic Development of Middle Income Countries", University of Chicago Law School, April 21-22, 2012, Chicago, USA. 


\section{Law and Development in Central and Eastern Europe: Neoliberal Developmental State and Its Problems}

\section{Introduction}

The major part of the regulatory structures in contemporary Central and Eastern Europe $(\mathrm{CEE})^{1}$ was built during the age of the Washington consensus. The term Washington consensus usually refers to a set of policies advocating economic liberalization, privatization and fiscal austerity, which were initially designed in the 1980s and 1990s by the IMF, the World Bank and the US Treasury to respond to the economic crisis in Latin America. ${ }^{2}$ Later, a similar set of policies was applied to former communist countries in CEE. As we know today, the Washington consensus had a strong anti-statist bias. More attention was paid to courts, judges, property law, contracts and less to administrative agencies, civil servants and regulatory policies needed to implement various developmental policies of the state. The neoliberal ideology ${ }^{3}$ underpinning the Washington consensus was anti-statist in the sense that it did not provide much room for the state as a regulator of economic activity. According to the mentality of the time, "the main thing that needed to be done was to get the state out of the way, and somehow everything else would take care of itself". 4 The only role left for the state was to protect property rights, enforce contracts, and protect against arbitrary use of governmental power. ${ }^{5}$ Apart from that, the market was considered the optimal mechanism for regulating the economic activity. As succinctly argued by Kennedy, the aim of the legal program of neoliberalism

Was not an improved exercise of state power but to disentangle the state from the market and establish more effective restrains on government rent-seeking and public choice bickering. All this was to be done by law. ${ }^{6}$

The neoliberal legal theory was highly formalistic. A great emphasis was placed on formal rules aimed at constraining public authority on one hand and at creating "the right rules" for market actors on the other. The importance of formal rules was so great that the law and development paradigm from the early 1960s was replaced with "the rule of law" model. ${ }^{7}$ As Sherman argues, "a central characteristic of this rule of 
law project was the idea that the formalization of Western-style law in the developing world was sufficient for promoting economic development." ${ }^{8}$ Furthermore, according to the rule of law model, only one model of the rule of law was appropriate for all countries. This rule of law model was comprised of a set of institutions which are typically found in Anglo-American countries. Therefore, the rule of law model was accompanied by a strong belief in the possibility of legal transplantation. ${ }^{9}$

With a major emphasis on property, contracts and administration of judiciary, the rule of law model almost completely disregarded the importance of public law. i.e. the role of regulatory agencies, civil service and public regulation of markets. It is hardly a surprise then that during the initial stage of the transition public administration reforms were not given the attention they deserved. As Suleiman argues,

One of the most striking aspects of the transition process in Central and Eastern Europe was the absence of recognition, at least in the essential phase of the transition, that a professional bureaucracy is crucial to both the consolidation of the democratic process and the imperatives of economic development" ${ }^{10}$

It was only during the accession period of the EU enlargement that reforms of public administration emerged high on the agenda both of the CEE governments and the Commission. But given the prevalent mentality of the time, even the EU-initiated reforms of public administration could not escape from the dogmatic formalism of neo-liberal development experts. In other words, civil service reforms, anti-corruption campaigns, transparency initiatives and, more recently, creation of new developmental agencies, were mostly about creating more and more new rules. If the rules did not function, then they were replaced with a new set of rules.

After the crisis of 2008, a new "post Washington consensus" (PWC) is emerging and it is calling for a new role for the "visible hand". According to Fukuyama and Birdsall, one of the consequences of the crisis is the rise of various new sorts of state intervention (industrial policy) which markedly differ from the old style strategy of picking the winners in East Asia and Japan. ${ }^{11}$ Examples of such new forms of state intervention are found in countries like China, Brazil, India and South Africa. The PWC also builds on ample historical evidence, showing that "today's most advanced economies heavily relied on government intervention to ignite and facilitate their 
take-off and catch-up process." ${ }^{12}$ Amsden, Chang, Gerschenkron and Wade have shown how various forms of state intervention contributed to the rapid development of Britain before the $18^{\text {th }}$ century, Germany, France and the United States in the 19th century, and Nordic countries, Japan, Korea, Taiwan, Singapore, Malaysia and other East Asian countries in the $20^{\text {th }}$ century. ${ }^{13}$

According to Trubek, we are witnessing an emergence of a new type of developmental state, a new developmental state (NDS). ${ }^{14}$ One of the key features of NDS is its ability to foster the process of learning and discovery as the central ingredient for a successful developmental state. As a consequence, the proponents of NDS are critical of the "one-size-fits-all" approach:

Scholars have pointed out that even if it is necessary to have institutions for certain functions, there are different ways to deal with such functional needs. And they have noted that given the social embeddedness of economic institutions, it is often impossible successfully to "transplant" institutions from one nation to another. They argue that development policy must allow each nation to shape its institutional structure according to its own needs and traditions. ${ }^{15}$

What distinguishes these NDS from the industrial policies of the $60 \mathrm{~s}$ and $70 \mathrm{~s}$ is their ability to coordinate between public and private actors in order to address coordination problems that discourage private investment in new industries and technologies. Some of the other key elements of NDS are: a major role for the state in steering investment, coordinating projects and providing information especially in projects with multiple inputs and long term payoff; extensive collaboration and communication between public and private sectors; a strong interest in exports and relative openness to imports; direct attention to entrepreneurships, innovation, and new product development etc. ${ }^{16}$ As one of the key features of such new forms of developmental states is experimentation and learning, these new states need more flexibility and less formalism. As emphasized by Wade, many new developmental states "have low scores in terms of the formalization of their rules, yet have grown relatively fast over a sustained period. ${ }^{17}$ Various authors emphasize that NDS depend upon capable and autonomous bureaucrats, such as those found at the upper levels in China, which are capable of managing and coordinating sophisticated policies. But unlike in the CEE countries, where a legalistic and formal approach to administrative 
reforms was dominant, the new developmental states emphasized the state's capacity "to coordinate agents, stabilize their confidence in the states' behavior and establish national development as an urgent overarching project." ${ }^{18}$ As the key features of these NDS, Wade lists evenly balanced power between the state and the business, an activist, public service oriented mindset of public officials, creation of bifurcated political and economic administrative structures, and an absence of significant discretionary power of budget resources on the side of public officials who are doing the nudging of private firms. ${ }^{19}$

In the first part of the article, I describe the origins of neoliberal developmental states in CEE. I start with the outline of administrative reforms during the age of the Washington consensus and examine how the neo-liberal legal policies and theories affected the administrative structures built in that period. I try to show that under the influence of the neoliberal "rule of law" model CEE developed a distinct, neoliberal developmental state. During the early stage of administrative reforms, they followed a one-size-fits-all approach and hastened to transplant various Western-style administrative structures without paying sufficient attention to social context and disregarding the policy relevance of such rules. I use the example of civil service reforms because they were at the epicenter of the first stage of administrative reforms. In the second part of the article, I discuss the EU-inspired innovation development policies, which gradually emerged as a major albeit truncated version of developmental policy in CEE. But then again, the inadequacy of the administrative structures built during the early stage of transition turned out to be one of the key inhibiting factors that prevented these new development policies from succeeding. However, as the Strategy for Poland, the only alternative development strategy to the Washington consensus in the region shows, selection of adequate economic policies is as important as the creation of adequate legal and political institutions. Poland achieved remarkable economic results with institutions which were considered to be inadequate by actors like the EU, the World Bank and IMF. I conclude with general observations about the importance of CEE examples for development policies of other middle-income countries (MICs) in the region. 


\section{What Kind of Developmental State: Institutions or Policies?}

The situation in CEE countries could not be more different. CEE countries face the current economic crisis with regulatory structures and policies that are quite different from the ones of NDS. Under the strong influence of the Washington consensus and its rule of law paradigm, they developed a distinct type of developmental state, a neoliberal developmental state. Not an oxymoron, this type of developmental state is characterized by excessively formalized regulatory structures, a strong reliance on pro market (neoliberal) economic policies and an almost complete neglect of autonomous developmental policies. As a consequence, CEE are ill prepared to tackle new challenges described by the PWC. While there is, as a result of the current economic crisis, an increased functional demand for all kinds of new regulatory policies and structures, there is only a few high quality regulatory structures and policies in place in CEE. Namely, civil service is prone to politicization and corruption, the public sector (education, health care) is in grave need of modernization and various regulatory bodies and structures outside the core government (anti corruption commissions, developmental agencies etc) lack necessary independence and credibility. And paradoxically, there is still very little demand in these countries for autonomous developmental policies. But, as we are reminded by the "post Washington consensus", "development has never been something that the rich bestowed on the poor but rather something the poor achieved for themselves." ${ }^{20} \mathrm{CEE}$ countries are no exception. In other words, without appropriate development structures and policies in place they may well remain a periphery or the "unfinished part of Europe". ${ }^{21}$

During the last decade, many of the CEE countries have made improvements both in terms of their economic growth and in terms of better quality of their institutions. According to the latest World Bank data, Slovenia, the Czech Republic, Hungary, Poland, Slovakia, Croatia and Estonia are now all high-income countries (HICs) by World Bank standards, and with the exception of Slovenia (23,610 GNI), all in the 12,480 to 18,500 GNI per capita range. ${ }^{22}$ Similarly, using the WB good governance data, we can discern that these countries outperform CEE middle-income countries 
(MICs) in terms of good governance indicators such as the rule of law, government effectiveness, and regulatory quality. ${ }^{23}$ As far as rule of law is concerned, Estonia, Slovenia, Czech Republic and Hungary are the top performers among CEE. However, if we compare the same indicators over the last 12 years for the same group of countries, we find only small improvements or no improvements at all. The World Bank's ongoing study of good governance concludes that there is no evidence of any significant improvement in governance worldwide. ${ }^{24}$ The latest Nations in Transit 2012 Freedom House Report Fragile Frontier: Democracy's Growing Vulnerability in Central and Southeastern Europe ${ }^{25}$ reaches similar conclusions. Over a period of five years, Nations in Transit findings have shown a clear backsliding in key governance institutions across the region. Six out of ten EU member states in the region (Hungary, Bulgaria, the Czech Republic, Lithuania, Romania and Slovakia) have experienced net declines over the past five years. As far as other MICs in the region are concerned, the Nations in Transit Report documents "an antidemocratic trend", a "democratic decline", "which raises real doubts about the prospects for widening the circle of democratic states in Europe." ${ }^{26}$ Similarly, Peerenboom argues that "while some MICs have improved their institutional capacity, institutions remain weak relative to developed countries, particularly in transitional states or states undergoing major political instability." 27

In other words, despite much enthusiasm since they had joined the EU, which led serious thinkers to declare that while CEE may not look exactly like the old member states, they nonetheless belong to the same broad category of democratic and liberal states, the picture of CEE today is not so rosy. As a leading economic historian, Berend, observes:

Looking back to the last two centuries, the picture is rather depressing. In relative terms, comparing to Western Europe, Central and Eastern Europe is far behind its 1820 relative level, and could not reach the 1870 relative level either. ${ }^{28}$

Furthermore, if CEE countries continue to grow twice as fast as Western European countries, they would need at least half of the 21 century to catch up with the West. ${ }^{29}$ If CEE economies are almost half a century behind the West, what conclusions can be drawn about the quality of their legal and political institutions? 
According to the New Institutional Economics (NIE), an influential economic theory, institutions are a key variable which distinguishes between successful and failed development. ${ }^{30}$ Under the influence of such thinking, the IMF and the World Bank substituted the market-oriented Washington consensus with a good governance regime which sees the poor quality of institutions as the root cause of economic problems in developing countries. ${ }^{31}$ Interestingly, although the good governance approach attributes high importance to institutions, its theory about "proper" institutions is not so different from its predecessor, the Washington consensus. ${ }^{32}$ According to the good governance approach, it is mostly institutions that maximize market freedom and most strongly protect private property rights, which are the best for economic development. One of the leading developmental economists, Chang, criticizes this approach as assuming that the causality runs from institutions to economic development and neglecting the other direction, where economic development creates better institutions. As he argues, there is substantial historical evidence showing that the causality may be stronger in the latter direction:

Today's rich countries acquired most of the institutions that today's dominant view considers to be prerequisities of economic development after, not before, their economic development- democracy, modern bureaucracy, IPRs, limited liability, bankruptcy law, banking, the central bank, securities regulation, and so on. ${ }^{33}$

Chang's arguments have two important implications for the development theory. First, if Chang is right about the causality, then developing countries would be better off to invest financial and human resources in policies that "more directly stimulate economic development- be they educational expenditure, infrastructural expenditure, or industrial subsidies- especially when they also indirectly promote institutional development, which can they further promote economic development." ${ }^{34}$ In other words, instead of trying to copy the institutions from developed countries, they should develop their own development policy, which should be more directly oriented toward economic development and growth. Otherwise, as Chang argues, they may end up with institutions that are more developed than what their standards of material development would strictly demand, which further complicates their attempt to identify the exact relationship between institutions and development. Second, the good governance approach strongly advocates the so-called Global Standard 
Institutions, which are typically found in Anglo-American countries, and are said to maximize market freedom and protect private property most strongly. Chang criticizes this view as too simplistic and historically inaccurate. For example, during the Golden Age of Capitalism (1945-1970), many rich countries adopted various forms of regulated capitalism and grew three to four times faster than during the period of classical liberalism (1820-1914) and twice as fast as than during the neo-liberal period (1980-2009). ${ }^{35}$ Moreover, the relationship between institutions and economic development changes over time. What might be good for one country in a certain period is not necessarily good for another country facing different circumstances. When developing countries fail to reach expected results, they are usually told to change the institutions instead of changing the policies which might not be appropriate for them. The latter course was usually not taken by developing countries because the straitjacket of neo-liberal theory, undergird by conditionality of financial support and loans offered to those countries, did not allow deviations from a seemingly universal applicability of various policy measures such as deregulation, privatization or liberalization.

\section{Building Neo-Liberal States in Central and Eastern Europe}

Reforms of national administration in CEE countries were not a key policy priority during the initial stage of the transition. Given the anti-statist bias prevalent among the reformers of that time, this is not surprising. It is only during the accession negotiations with the EU that administrative reforms became an important item on the policy agenda of the CEE governments. More precisely, with very few exceptions, most of the governments started with various reforms of public administration only in the second half of the 1990s. Before that period, the neoliberal development experts were more interested in un-building and dis-establishing prior communist state structures than in building new ones.

As one early study on the transition reports, the neoliberal experts deliberately weakened potential agents of industrial restructuring in the region. For example, in Poland and Hungary, the World Bank explicitly required respective governments to 
disempower the ministries of industry, responsible for development and industrial policy, while providing both technical and financial assistance to ministries of privatization, which became the most effective government bureaucracies in the region. In Poland, the ministry of privatization had a special status within the government and was exempt from ceilings on civil service pay scales, which enabled it to attract the most capable staff members. ${ }^{36}$ Next, the World Bank imposed a de facto ban on development banking. The Polish Development Bank's autonomy to lend directly to industry was limited by the World Bank's loan conditions. The theory behind such institutional un-building was the "do nothing policy", based on the idea that once proper institutions for the market economy had emerged, the markets would do the rest of the job. Instead of pursuing their own industrial or developmental policy, CEE countries invested heavily in various structural reforms, another term used by the Washington consensus ideology, which amounted to de-industrialization rather than re-industrialization.

The EU-initiated accession negotiations with the candidate countries of CEE brought important modification to the previous neoliberal anti-statist policy. Since a vast part of the EU administration depends on indirect administration carried out by member states, it is unsurprising that the Commission decided to scrutinize the administrative capacity of the CEE's national administrations to apply the "acquis". As Verheijen observes, "too wide a divergence in administrative capacities between member states to transpose and efficiently implement EU legislation could lead to serious distortions in the functioning of the Internal Market." 37

\section{Example: Civil service reforms}

The Commission strongly insisted on the adoption of civil service legislation as a start for administrative reforms. In other words, adoption of civil service legislation, coupled with some additional measures such as the development of a training system, adequate policy development and policy-coordination capacities, became almost synonymous with administrative reform itself. While the adoption of civil service legislation was carefully scrutinized by the Commission, other aspects played a less prominent role. Adoption of civil service laws was too often understood not as a first step in administrative reform but as an end in itself. The legalistic nature of civil 
service reforms can be explained by the insistence of the Commission on adoption of civil service laws and by the prevailing legalistic tradition in CEE countries. As one of the principal SIGMA advisers argued, their

\begin{abstract}
Approach to public administration reform has been basically and necessarily a legal approach because the change required from candidate countries by the EU is mainly about changing the rules of the game and building a new legal order for public administration that is compatible with EU membership aspirations. ${ }^{38}$
\end{abstract}

It is very interesting that the SIGMA ${ }^{39}$ and the Commission, sometimes implicitly, sometimes explicitly, promoted requirements for the adoption of the classical Weberian model of centralized hierarchy, with the emphasis on formalization of civil service management and the minimization of managerial discretion, which are needed to strengthen the principles of legality, professionalism, impartiality and depoliticization. ${ }^{40}$ The Weberian model comes close to the continental Rechtsstaat tradition of public administration with its roots in Max Weber's ideal type of rational/legal bureaucracy. ${ }^{41}$

There was not much discussion of the New Public Management (NPM) model ${ }^{42}$, the most influential model for civil service reforms in Western Europe at that time, or of any other models of development. Since the strong communist legacy of overt politicization of public administration was still alive in most of the CEE countries, one can understand why the Commission and SIGMA sincerely believed that depoliticization and establishment of professional and neutral public administration should become a priority in administrative reforms in CEE. However, it is a little more difficult to understand why such a reform should preclude any borrowing from the NPM or any other alternative model. As a consequence of the Commission's insistence, most of the CEE countries hurried with the adoption of civil service laws. While before 1997 only Hungary, Poland, Latvia, Estonia, and Lithuania had passed civil service legislation, in the period from 1997 to 2002, all other CEE countries had done so. The Slovak law from 2001 "was a formality designed to satisfy the European Union." 43

The strong insistence of the Commission and the SIGMA on the classical Weberian model basically limited the range of policy options available to CEE countries. One of 
the false dilemmas the CEE countries were confronted with was a choice between the classical Weberian model of bureaucracy and the more flexible model of civil service, favored by the New Public Management writers. The head of OECD-SIGMA argued that CEEs should first establish a classic Weberian model of public administration. $\mathrm{He}$ strongly urged the CEE not to experiment with NPM solutions, because too much NPM could lead to unpredictability and corruption. Such a preference for the classical, Weberian model of public administration, coupled with an over-reliance on law and legislation, produced a distinctive 'legalistic' approach to administrative reforms, where passing civil service laws became almost identical to administrative reform itself. As Verheijen critically argues, "the adoption of laws was considered the panacea for addressing problems such a politicisation, fragmentation and instability." 44

The pre-accession civil service systems in CEE suffered from some common problems and dysfunctions. These systems were plagued by a strong politicisation of civil service, an absence of a culture of political neutrality, a lack of mobility in civil service personnel policy, decentralisation and fragmentation of personnel and pay policy, the lack of a central agency responsible for the recruitment and dismissal of civil servants, poorly paid staff, and last but not least, a poor image of the civil service. Verheijen argues that adoption of civil service laws "has not resolved the problems of instability and politicisation and has rarely led to the development of a well-working system of long-term career development." ${ }^{45}$ A World Bank study also reports about "a mixed picture of overall setbacks, especially since accession with some promising innovations, particularly in the Baltic States." ${ }^{46}$ One of the setbacks has to do with the return of politicization. The study reports that "the very idea of an impartial and professional civil service, based on merit and continuity, appears to have lost its appeal to the political leadership of most of the new Member States." 47

Quite paradoxically, few years after the accession, the politicization of civil service in Poland, Hungary, Slovenia, and Slovakia has reached a critical point, leading Adam Michnik to declare the Polish civil service corrupt. ${ }^{48}$ Meyer-Sahling argues that Slovakia, the Czech Republic, Poland and Slovenia are cases of post-accession reform reversal. Hungary is a case of reform reorientation. Only the three Baltic states continued with professionalization and depoliticization of civil service. ${ }^{49}$ The Polish, 
Hungarian and Slovenian government amended their civil service laws to allow more political appointments in the civil service. A major reform of civil service law in 2006 in Poland abolished civil service office and redefined senior civil service jobs such as directors general, directors of departments, and deputy directors of departments as political appointees. As a consequence, the entire civil service was under the direct control of the Prime Minister's office and special civil service examinations were abolished so that politically loyal but unqualified newcomers could replace existing civil servants. ${ }^{50}$ The Polish government replaced hundreds of board members of state enterprises with their friends and cronies. Interestingly enough, new public management ideas did not influence Polish policymakers. The reforms were justified as part of the anti-corruption crusade of the Kaczynski government of that time. In Slovenia, politicization reaches downwards toward non-managerial ranks in the civil service. Slovenia also passed a new Salary Act with the aim at centralizing and rationalizing the pay system in the public sector. The Salary Act is so rigid and formal that it leaves almost no discretion to heads of units and organizations for flexible pay policy. A recent OECD study recommends a substantial reform of the act criticizing its too heavy rigidity and formalization of the entire pay system. ${ }^{51}$ According to the first comparative study of politicization of senior civil service, Slovenia belongs to a group of countries with the highest score on politicization. The most politicized senior civil service is in Slovakia and Poland, followed by Hungary, the Czech Republic and Slovenia. The lowest scores belong to the Baltic states, Estonia, Lithuania and Latvia, which have the least politicized senior civil service. ${ }^{52}$ Hungary, in the 1990s the frontrunner in civil service reforms, continued with further politicization of senior civil service positions as well as human resource management responsibilities. Interestingly, the Gyurcsany government amended the civil service law in 2007 with a reformist program heavily influenced by new public management thinking. ${ }^{53} \mathrm{~A}$ new government personnel center was established with the idea of improving the quality, competitiveness and transparency of personnel policy. Moreover, the new competence-based evaluation system and modernized performance-related pay system were introduced. A new performance-related pay system allows an annual bonus of six monthly salaries as a reward for outstanding performance. The system has implementation problems also due to major resentment among civil servants. Given the unstable political situation in Hungary after March 2008 and with the new Orban 
government, it is unclear whether and how these reforms will be implemented. Slovakia passed a major amendment to its civil service law in 2003 deregulating the salary system and introducing a highly discretionary bonus system. Furthermore, with another major amendment in 2006, Slovakia abolished the Civil Service Office and transferred civil service management authority to the Ministry of Labor and the Government Office. Slovakia politicized the rank of Head of Service Office, the highest civil servant, and removed the job protection for Directors General and other senior civil servants. Like in Hungary, a combination of more discretionary salary and performance systems with dismantling of job protection of senior civil servants in both countries led to increased politicization of civil service. ${ }^{54}$

On the other side of the spectrum we find the Baltic countries which have the least politicized senior civil service in the region. In Latvia, even the Secretary of the State at the top of the civil service is subject to very limited political control. Latvia, known for introducing management contracts allowing ministers to negotiate salary deals with their officials, further modernized the salary system and introduced a performance-related pay system, thus strengthening the managerial discretion in the salary system. A similarly depoliticized, professionalized and managerial performance pay system was introduced in Lithuania. Estonia's civil service, according to Meyer Sahling, "stands out with low levels of politicization and a well-entrenched ethos of professionalism." 55 The Baltic states, particularly Estonia, were heavily influenced by the Swedish and Finnish model of public administration. One of the key differences between the Scandinavian and other continental European models of public administration is a greater degree of flexibility and managerialism in the first group.

CEE countries, with the exception of Baltic states, adopted the wrong strategy of administrative reforms. With an over-reliance on legislation, buttressed by a strong legalistic tradition already present there, CEE sought to adopt new civil service laws first, and reform people later. As Verheijen argued, first they should have designed appropriate strategic approaches, invested more in training and education, and devoted more time to tackle structural problems. For example, to tackle the problem of overt politicization with almost exclusive focus on legislative aspect of reforms is not a good strategy: "designing and adopting civil service legislation without attacking the root causes of the problems in the administration in the first has proved 
to be a highly inadequate reform strategy." ${ }^{56}$ Depoliticization of the civil service is an immensely difficult task. Most developed democracies in the West spent decades building a political culture of neutral and apolitical public administration. On the contrary, as Meyer-Sahling shows, the political parties in the region were locked in the spiralling process of the continuous politicization of civil service, where each newly elected government suspended or radically modified the administrative reforms of its predecessor. ${ }^{57}$ In such a climate of heightened political distrust among the key political actors, it is nearly impossible to agree and even more difficult to implement any serious administrative reform. Administrative reforms in developed democracies are usually piecemeal and take several years to develop. They require the strong support of all major political forces. Without changing training and education systems first, it is very näive to believe that passing a new law would solve the problem by itself. Yet, in all CEE we can discern almost a fetishist focus on the production of new legislation which was often dissociated from its own implementation. Such processes often degenerated into "symbolic politics" resulting in adoption of laws which cannot be enforced.

\section{Institution building and/or development policies: the Polish alternative?}

As the example of civil service reforms shows, CEE, with the Baltic exception, still lack a competent and professional bureaucracy which is sufficiently capable and autonomous from political patronage. And yet, "promoting effective public sectors is one of the most daunting development challenges that the world faces." ${ }^{58}$ Such a bureaucracy is a prerequisite urgently needed in a country contemplating any use of newer forms of industrial policy. Many Asian countries like Japan, Korea or China relied on a long tradition of strong professional bureaucracy. Heavily influenced by the private rule of law formalism of neo-liberal theory ${ }^{59}$ and rigid Weberianism of EU policy makers ${ }^{60}$, CEE created institutions which, compared to the West, are "more formal, more constraining of public authority over the economy, less open to institutional variation and less well embedded in the local institutional, social and economic context." ${ }^{61}$ As in private rule of law formalism, the focus shifted from public to private law, law then emerged primarily as a limit on the state - on the discretion of administrators and the mandate of legislation. ${ }^{62}$ As Kennedy argues, "the 
goal was less to ensure that state functionaries understood the needs of national development, than that both public and private experts understand the needs of (largely foreign) capital and are able to formulate rules to "open markets" and encourage its arrival." ${ }^{63}$

Quite paradoxically, as CEE focused on formalistic rules aimed at limiting discretion and undue political influence over bureaucracy, they ended up with civil service structures which are neither sufficiently competent nor autonomous from political pressure. But civil service is not the only example showing such results. A very similar pattern can be found in other areas of institutional reforms in CEE such as anti-corruption campaigns, transparency legislation and creation of new developmental agencies. ${ }^{64}$ It is an excessive focus on rules and legislation, disassociated from policy goals and social context, which has largely contributed to the creation of such "formal structures without substance": i.e, institutions which look similar to its Western style counterparts, but fail to produce expected results. ${ }^{65}$

As Trubek ${ }^{66}$ and Kennedy ${ }^{67}$ argue, different theories about law and development are always embedded in different theories of political economy, which in turn means that law is embedded in different development policies. Hence, neoliberal developmental states and their legal institutions were embedded in various forms of neoliberal capitalisms which emerged in CEE. During the first two decades of transition (19892009), CEE countries evolved into three distinct types of capitalism. ${ }^{68}$ The first two types, present in the Baltic (Estonia, Latvia, Lithuania) and Visegrad states (the Czech republic, Poland, Hungary, Slovakia), represent variations of neo-liberal capitalism. Only the third type, found in Slovenia, represents a distinct type of neoliberalism embedded in corporativist institutions and a generous welfare state. ${ }^{69}$ A common characteristic of these various neoliberal types of capitalism during the early transition period was almost a total absence of any indigenous developmental policies. A comparative study of industrial policy in the region finds that "...Basically any government role in industrial development was challenged as a return to former policy practices, and a "hands-off" pattern of industrial policy seemed to prevail in most CEECs." 70 
Consequently, in the entire region there was very little demand for other than neoliberal developmental policies. Parts and pieces of industrial policy could be found in many different forms and variations but they never developed into a more comprehensive, systematic development policy. The only two major exceptions to this neo-liberal preemption of alternative development strategies were the Polish "Strategy for Poland" plan in the 1990s and the innovation policies in some CEE countries initiated by the EU structural funds.

The Strategy for Poland was the only development strategy in the region to explicitly reject the doctrine of Washington consensus. Its major architect was the Polish deputy premier and finance minister at the time, professor Grzegorz W. Kolodko. ${ }^{71}$ From 1994 to 1997, Poland achieved an outstanding economic performance topped by other measures that improved social welfare of Polish citizens. The left-center Polish government combined a pragmatic economic approach which included "heterodox" economic policies running against the neo-liberal prescriptions, with gradual improvements in the market economy institutions. Instead of immediately privatizing the entire state sector, Kolodko's government implemented a commercialization of the public sector, which meant that state-owned enterprises were exposed to competitive pressure and subjected to tough budget constraints, similarly to the private sector. On the other hand, privatization was "rationalized" in order to help improve the double goal of microeconomic efficiency and maximizing government revenue. In short, "neoliberal doctrinarism was abandoned for a pragmatic approach based on economic rationalism". $^{72}$ Kolodko's government was also aware of the importance of institutional infrastructure required to make a market economy function. ${ }^{73}$ Last but not least, Poland emphasized some things which were usually neglected by the IMF, such as the importance of democratic support for the reforms, which entailed its concern to keep unemployment low, to provide benefits for the unemployed and to adjust pensions for inflation, and also the importance of public dialogue and social partnership with trade unions and business organizations. ${ }^{74}$

According to Kolodko, the Strategy for Poland, together with the Programme of the Reform of Public Finance (2002-2003), when he resumed the position of deputy prime minister and finance minister, essentially made Poland a success story among the post-communist economies. Poland is the only country in the region to almost 
double its GDP from 1989 to 2010. Nevertheless, as Kowalik shows, the story of Polish economic "success" is not without its own contradictions and problems. ${ }^{75}$

However, according to the new institutional economics, given the low-quality of the Polish bureaucracy at the time, such poor-quality institutions could not have lead to spectacular economic and social results as achieved in Poland. In order to explain the success of "East European tiger", we have to return to the critique of NIE as developed by Chang and Fukuyama.

As Chang argues, the choice of appropriate policies, especially when they also indirectly promote institutional development, may be more important for development than the design of institutions as such. As he argues, the causality often runs from economic development, economic policies to institutions. Kolodko, being himself very much aware of the institutional aspects of development, has contributed a lot to the subject of the theory of systemic change in transition economies ${ }^{76}$ as well to unorthodox development economics. ${ }^{77}$ Instead of focusing on the neoliberal formalized approach to institutions, Kolodko's government adopted more pragmatic and policy- oriented style of administrative reforms. Special attention was given to the recruitment of qualified people, special programmes for teaching and training were established, and special code/regulation on civil service was introduced. Kolodko was doing his best to engage the non partisan technocrats and pay them as much as the budget could afford. ${ }^{78}$

This was quite different from other CEE which were mostly preoccupied with building "ideal" institutions as propagated by the neoliberal "good governance" doctrine. With such "imperfect" institutions, the Polish government pursued pragmatic economic policies which in combination contributed to spectacular economic results. Therefore, the Polish alternative strategy does not show that institutions are not important. What it shows is that "effective institutions have to evolve indigenously, reflecting a country's own political, social, and cultural realities....Institutions such as the rule of law will rarely work if they are simply copied from abroad; societies must buy into their content." 79 As Fukuyama argues, there are many countries, beginning with China, which have developed rapidly in the absence of "good governance" institutions. But there are also countries like the US and Britain which made the 
industrial revolution with governments that were substantially more corrupt and less capable than they are today. ${ }^{80}$ What matters most is that institutions are relevant and appropriate for a country's development goals and policies, and second, that institution building is not treated as something prior or separate from formulation of development policies. And, as the Polish case reveals, it is equally important that country has a "right" development policy in the first place. By rejecting the neoliberal orthodoxy of "do-nothing" industrial policy and replacing it with more pragmatic "heterodox" economic policies, Poland achieved better economic results than countries which simply followed the neoliberal advice.

The second major exception to "do-nothing" industrial or development policy in CEE is the innovation policy which was heavily promoted and supported by the EU structural funds starting in 2004.

\section{Towards neoliberal developmental states in CEE}

\section{Example: Innovation policy as development policy}

Since 2004, innovation policies in CEE represent the most important form of industrial policy with a much more active role of the state. ${ }^{81}$ During the first stage of transition, innovation policy was basically substituted by the Washington consensus policies of "structural adjustment". The innovation policy proper was not considered important to the neo-liberal development experts. Almost all economic capacity building was directed toward macroeconomic issues:

Industrial policy thinking of the early transition governments was characterized by an outspoken liberal approach, leaving structural change entirely to the market. ${ }^{82}$

Already in the late 1990s, such an approach to industrial policy gradually began to shift to various forms of more horizontal innovation, technology, and regional policies, all representing an EU "implicit" version of industrial policy. All these various policies are part of the EU cohesion policy, which aims to reduce social and economic disparities and is conceptualized as "a partial counterbalance to the natural effects of the internal market by promoting a more balanced distribution of resources and economic development across the EU." 83 The main policy instruments of 
cohesion policy are the Structural and Cohesion Funds, which account for 40 per cent of total EU budget (347 billion euros). During the 2007-13 financial perspective, the innovation policy as a part of a broader set of initiatives known as the "knowledge economy" became one of the key priorities financed through the structural funds. ${ }^{84}$

Most of CEE made extensive use of the EU structural funds to promote their "implicit" industrial policies. For that purpose, most of CEE created special purpose agencies: the Agency for Enterprise Development in Poland (2000), the Slovak Innovation and Energy Agency (SIEA) 2007), the Lithuanian Science Council (2008), the government's technology policy agency (OMFB) in Hungary and several ministerial executive agencies in Slovenia. Due to the requirements of EU law on structural funding requiring regional and local institutions to administer the EU funds, a multilevel, decentralized system of various implementation agencies and other bodies, on the national, regional and local level was created subsequently. As a more complex, decentralized, and collaborative framework for industrial policy was created, it was clear from the outset that more traditional, top down, statist versions of industrial policy were ruled out in this policy area.

However, as it turned out later, it was precisely this decentralized and fragmented institutional network which caused some major problems in developing successful innovation policies in the region. As one comparative study of innovation policy in the region argues, one of the major problems was caused by "increasing usage of independent implementation agencies in an already weak administrative capacity environment lacking policy skills for networking and long-term planning." ${ }^{85}$ As a consequence, while Europeanization of innovation policy has had many positive effects, it has also contributed to "deepening and exasperating the existing problems of networking and coordinaton" ${ }^{86}$ in CEE regulatory framework. Moreover, "the lack of tradition of partnership and inter-institutional coordination and cooperation between administrative levels on the other hand, meant that most positive effects of such agencies were not reaped and that they created in some cases more difficulties and problems than they solved." 87 What is particularly interesting is not that such problems existed during the accession period but that they were exacerbated during the current period. The same study reports that "almost all CEE innovation policy implementation problems go back to very weak and disorganized actors, coordination 
problems are rampant in policy design and innovation/industry on the ministerial level and its delivery system. ${ }^{18}$ The fragmented policy making system suffered from acute absence of cooperation and learning between different actors like governments, industry and research organizations. In other words, creation of multiple independent agencies was one of the key innovation policy problems in CEE.

As different comparative studies on independent agencies show, one of the most difficult tasks is to create agencies which are sufficiently independent but flexible enough (which usually means not too independent) to allow policy coordination. ${ }^{89}$ Too much independence, coupled with fragmentation of the number of agencies, could lead to severe coordination problems between the principals (ministries, development bodies) and agents (independent agencies), as well as between the agencies themselves. In such a context, it is not clear formal rules which usually help to ameliorate coordination problems, but other factors such as administrative culture, shared policy agenda among the actors, and informal channels of coordination. Most of these informal prerequisites are simply lacking in the CEE context. To make things worse, at the top of the system sits civil service which also lacks most of the attributes important for policy coordination of the entire framework.

Innovation policies in CEE also suffer from wrong substantive policy choices which are not necessarily related to the previously described problems of policy structures. One of them has to do with a linear understanding of innovation ("from lab to market") which assumes that there is a growing demand from industry for innovation products resulting from innovation policy:

Innovation is seen as something close to science and invention, and that there is a more or less linear correspondence between scientific discovery and high innovation performance, and that innovations behave like Nokia's mobile phones and thus search for the la became the holy grail of CEE innovation policy. ${ }^{90}$

It is no surprise then that many of the innovation policies tend to solve the problems which are nonexistent in the industry. While the industry specializes in just few research-intensive and high skill products, the innovation policies concentrate on high technology sectors, on commercializing university research, technology parks for start-ups etc. Furthermore, the innovation policies are horizontal and less focused on 
specific sectors or industries, what in turn contributes to high fragmentation of policy measures. Coupled with already fragmented institutional framework, such misguided innovation policies cannot deliver expected results. Indeed, as a recent EU annual scoreboard revealed, CEE lag much behind West European countries in innovation policy results. ${ }^{91}$

While the example of innovation policy clearly shows the importance of an adequate institutional framework for a successful developmental policy, it also reveals that creating appropriate institutions is not a separate process from devising appropriate policies themselves. In other words, the structure of a neoliberal developmental state, created to promote neoliberal agenda, turned out to be inadequate for "post neoliberal" innovation/development policies. The example is also important because it comes closest to examples of new forms of developmental policies as practiced by NDS. Trubek offers a list of key features of NDS. Among them we can find organized systems for public-private information sharing, cooperative public-private efforts to construct regulatory regimes that foster global competitiveness and domestic efficiency, extensive collaboration and communication between public and private sectors, an emphasis on innovation, and new product development etc. ${ }^{92}$ As he further argues,

It is impossible to know the right developmental paths in advance, finding these paths requires experimentation, experimentation must involve public-private collaboration, and a successful path must include the appropriate legal and regulatory framework....policy must be flexible enough to permit a variety of efforts and regulatory frameworks must be sufficiently revisable so that the fruits of learning can easily be incorporated...If we wanted to sum up the NPED in a few words, it might be in envisioning development as a process of discovery in which the state seeks to empower the private sector and state and market function best when they are linked in collaborative structures that foster experimentation and revision. ${ }^{93}$

While CEE innovation policies were clearly informed by some general ideas about the importance of education, $\mathrm{R} \& \mathrm{D}$, and innovation, most of other elements of the new developmental state are missing. Again, like in the example of administrative reforms, CEE reformers subscribed to unduly formalized approach to institution building, 
without paying enough attention to other informal features required for such collaborative and decentralized policy framework to deliver expected results.

More informal approaches to institution building of regulatory structures are not found only among East Asian countries. ${ }^{94}$ They are also found in a diverse group of countries including Brazil, South Africa, and India. One cannot fail to notice a stark difference between an almost obsessive focus on formalization of administrative structures in CEE, and a more informal approach among the new developmental states. One lesson for CEE thus seems to be that these countries should abandon the overly formalistic approach to institution building and replace it with a new approach which understands the rule of law in a more informal, pragmatic and revisable fashion. This is not to say that the rule of law does not require formalization to a certain degree. My point is that a proper mix of formal and informal rules can be found and designed only through an indigenous process of institution building which allows each nation to design its development policy and institutions according to its own needs and traditions. ${ }^{95}$ The ideology of legal transplants, so typical for the age of the Washington consensus, should be replaced by a new legal approach of experimentation and learning.

The innovation policies in CEE, with all their flaws, represent a truncated and less ambitious version of development policy if compared to a variety of policies practiced by the new development states around the world. Unlike the NDS, CEE lack both institutions and polices required for the more sophisticated approach to development. The examples from this article show that while, on the one hand, the new policies represent an important break with the neo-liberal development thinking, on the other hand they still continue to be influenced by a strong residuum of the neo-liberal doctrines and policies. There is still very little demand for new autonomous developmental policies in CEE. As the case of innovation policy shows, even when they are in place, they are predominantly a result of the EU initiatives and less home driven. Nevertheless, these examples also show that devising a development strategy has to be done by the developing countries themselves. 


\section{Conclusion: Lessons for other MICs}

The lessons of failures and successes of neoliberal developmental states in CEE are not relevant only for CEE countries but also for other developing countries in the region. In the conclusion, I briefly discuss some of the lessons that might be important for other MICs in the region. While all CEE which are EU member states belong to a category of consolidated democracies, most of other MICs in the region fall into various categories of semi-consolidated democracies, transitional governments or hybrid regimes, semi-consolidated authoritarian regimes and consolidated authoritarian regimes. ${ }^{96}$ As such, they will continue to attract intellectual and practical interest of international and domestic actors searching for solutions how best to promote further development of these "nations in transit" toward democracy and the rule of law.

With the emergence of the "post Washington Consensus" it has become clear that there is no development without indigenously created developmental strategy by developing countries themselves. This observation represents a clear shift in the development agenda. A history of law and development in the last four decades shows that such agenda was usually generated in the developed world to be implemented later in the developing world. As the examples of NDS show, successful development agendas have to primarily emerge and grow locally. With the growing importance of countries like China, India, Brazil and South Africa, the developed world will have to accept the importance of their economic resources as well as their ideas. Ready-made models of legal texts, political institutions or economic policies will have to be replaced by much more dialogical and contextual debate between the donors and the recipients of developmental aid. In other words, the developed world and international institutions will remain important providers and donors of international best practices and financial resources for developing countries, but actual configuration of appropriate development models will have to be done at home, in the periphery. Therefore, MICs in the region would be well advised not to follow the path of CEE countries which, with the exception of Poland, substituted their development strategies with neoliberal "do nothing" industrial policies. The absence of "appropriate" institutions in many MICs should not be an excuse for not trying to 
create different development strategies. Needles to say, they will vary according to political, social and economic context of the country in question. As MICs in the region include some of the existing EU members (Lithuania, Latvia) with small and open economies and relatively well developed institutions modeled upon their Scandinavian neighbors, but also countries with large continental economies, weak political institutions, rich natural resources (Russia, Kazahstan, Azarbaijan), it is clear that development strategies of MICs will have to proceed along quite different developmental paths.

One of the most flawed views of the Washington consensus was that there is a single set of most appropriate institutions, including the rule of law, which are required for successful development. Such a "one-size-fits-all" model prevailed in the development thinking of the last fourth decades. One of the first leading economists to criticize such approach was Stiglitz. ${ }^{97}$ Unger developed a powerful legal critique arguing that such identification of institutional conceptions like representative democracy or a market economy with a single set of institutional arrangements represents a theoretically and historically flawed version of "institutional fetishism". Defending his theory of democratic experimentalism, he further argues that "representative democracies, market economies, and free civil societies can assume legal-institutional forms very different from those that have come to prevail in the rich industrial democracies". ${ }^{98}$ A more recent work on "varieties of capitalism" confirms that there are substantial differences among institutional forms of rich industrial economies. ${ }^{99}$ Institutions like parliamentary democracy, corporate governance, civil service or judicial review can assume many different forms. Only when we talk about them in highly abstract terms, it appears as if there are core institutional structures like an independent judiciary or accountable government, which any democracy based on the rule of law must assume. But with their further specification, we realize that there are many different forms that such institutional structures can assume. Civil service reforms in CEE offer a good example of such institutional fetishism. CEE were illadvised to follow specific models which turned out to be quite inappropriate from them.

As a consequence, the "one-size-fits-all" model of appropriate legal and political institutions has to be replaced with a plurality of different models, each suitable for a 
particular country or a group of countries. As Teubner argues, the logic of legal transplants has to be replaced with the idea of legal irritants. The theory of legal transplants wrongly suggests that "after a difficult surgical operation the transferred material will remain identical with itself, playing its old role in the new organism." 100 As he further argues, "when a foreign rule is imposed on a domestic culture, I submit, something else is happening. It is not transplanted into another organism, rather it works as a fundamental irritation which triggers a whole series of new and unexpected events." ${ }^{101}$ Instead of being told to copy legal transplants from the rich industrial economies, MICs should be encouraged to experiment with various forms of institutional configurations most likely to advance and promote their development. CEE, for example, invested too much resources in formal transplantation of various transparency and anticorruption codes, without paying sufficient attention to incentive structures likely to render such codes workable. In countries like Albania, Romania, Bulgaria or Belarus, it is even less likely that such formal transposition of transparency and anticorruption laws would work. As Batory suggests ${ }^{102}$, policymakers should move from almost exclusive focus on sticks and consider the potential use of carrots. In many situations, rewards for reporting corruption may have a greater effect than penalties. ${ }^{103}$

More recent literature on industrial policy ${ }^{104}$ reminds us that new development policies are by their nature experimentalist and process oriented. Since there is no single set of international best practices, new development policies require both learning and innovation. Such an approach requires a sufficiently capable and politically autonomous bureaucracy to exist. Needless to say, in most of the MICs, with the exception of Baltic states, such a bureaucracy does not yet exist. MICs in the region don't have a tradition of strong technocratic bureaucracy as it exists the developed world or in China. As Birdsall and Fukuyama argues, countries without such a tradition should be more careful. ${ }^{105}$ All these suggest that one of the top priorities for MICs should be promotion of effective public sectors. This will be especially difficult task in countries which have consolidated authoritarian or semiauthoritarian regimes. One of the prerequisites of effective public service is its autonomy and meritocracy. How to create such a bureaucracy in authoritarian regimes which also lack the legacy of a strong technocratic bureaucracy? As Birdsall and 
Fukuyama explain, "the development of impersonal bureaucracies in the West was the product of a long and painful process, with factors exogenous to the economy (such as the need to mobilize for war) playing a large part in creating state institutions (such as Prussia's famously efficient bureaucracy)."106

As Chang argues, today's rich counties acquired most of the institutions that are, according to the dominant view, prerequisite of economic development, after and not before their economic development. In other words, in many ways such institutions were rather a result than a cause of their economic development. Mungiu-Pippidi come to almost the same conclusion: "The explanation for the performance of historical achievers is not to be found in their present organization (legislation, political institutions) which should not be viewed as a cause, since it acts for the maintenance, rather than the creation, of good governance." ${ }^{107}$ This is particularly important for MICs which should avoid the institutional fetishism as promoted by the advocates of the Washington consensus. They should invest more in economic policies likely to promote economic development and approach institution building more pragmatically than other HICs from the region did. This is not to argue that institutions are not important but only to reverse the priorities and follow certain elements of the East Asian Model for development as described by Peerenboom. ${ }^{108}$ They should initially focus on economic growth, adopt a pragmatic approach to economic reforms but as the economy grows and wealth is generated, they should invest in human capital and institutions.

As a leading developmental economist argues, adopting such "second best" institutions in developing countries is a much better choice than trying to emulate the best practice institutions. The second best institutions are those that take into account context-specific market and government failures that cannot be removed in short order. As such, they promise more effective institutional framework conducive for economic development than "best practice" institutions, which are "almost by definition, not contextual and do not take account these complications". ${ }^{109}$ Almost the same conclusion is reached by Haggard, MacIntyre and Tiede in their systematic review of the literature dealing with relationship between the rule of law and economic development: "Yet for countries at low levels of development, the types of informal institutions that generated trade in early modern Europe may be more 
relevant than the complex statute and demanding institutions of the American or current European legal systems." ${ }^{110}$

In trying to get the law right, legal reformers in CEE too often overooked "that the life of the law, even in the well-appointed homes of the exporters of the rule of law, lies outside offical institutions as much as, arguably more than, it does within them."111 No surprise that"legal systems are among the most difficult and costly governmental systems to construct because they have huge infrastructure needs and require both human and physical capital." ${ }^{112}$ The rule of law promotion in MICs should therefore follow a different strategy. New institutions in MICs may in the end resemble their Western models. But what is more important is that they actually work well for MICs, even if they look different than their Western counterparts.

\section{Notes}

${ }^{1}$ In the article I discuss the EU member countries from Central and Eastern Europe. Among them, the Czech republic, Estonia, Hungary, Poland, Slovak Republic, and Slovenia belong to high-income countries (HICs), while Bulgaria, Romania, Latvia and Lithuania belong to middle-income countries (MICs).

${ }^{2}$ The term was coined by John Williamson in 1989. John Williamson, What Washington Means by Policy Reform, in John Williamson, ed., Latin American Readjustment: How Much Has Happened (Washington: Institute for International Economics, 1989), 7. Subsequently, the term aquired a broader meaning and usually connotes a market fundamentalism or neoliberal agenda. Justin Yifu Lin, Lessons from Great Recession, in Nancy Birdsall, Francis Fukuyama, eds., New Ideas on Development After the Financial Crisis (Baltimore: The John Hopkins University Press, 2011), 57.

${ }^{3}$ Neoliberalism represents the revival of economic liberalism which has been taking place since the late 1970s. Its main premise is that the market is seen as morally and practically superior to government and any form of political control. Andrew Heywood, Political Ideologies: An Introduction (Hampshire: Palgrave Macmillan, 2003), 54-55; David Harvey, A Brief History of Neoliberalism (Oxford: Oxford University Press, 2005), 2. 
${ }^{4}$ David M. Trubek, "The "Rule of Law" in Development Assitance: Past, Present, and Future", in David M.Trubek, Alvaro Santos, eds., The New Law and Development : A Critical Appraisal (Cambridge: Cambridge University Press, 2006), 85.

${ }^{5}$ Trubek, "The Rule "Rule of Law" in Development Assistance", 85.

${ }^{6}$ David Kennedy, Law and Development Economics: Toward a new Alliance, paper, 2008, 29.

${ }^{7}$ Trubek, "The "Rule of Law" in Development Assistance", 86.

${ }^{8}$ F.Charles Sherman, "Law and Development Today: The New Developmentalism", German Law Journal Vol.10.No.9 (2009); 1264.

${ }^{9}$ Trubek, "The "Rule of Law" in Development Assistance", 86.

10 Ezra Suleiman, Dismantling Democratic States (Princeton and Oxford: Princeton University Press, 2003), 287.

${ }^{11}$ Nancy Birdsall, Francis Fukuyama, "The Post-Washington Consensus", Foreign Affairs March/April (2012): 49.

12 Justin Yifu Lin, Celestin Monga, Growth Identification and Facilitation, The WB Policy Research Working Paper 5313 (May 2010): 8.

${ }^{13}$ Lin, Monga, "Growth Identification and Facilitation", 7.

${ }^{14}$ David Trubek, "Developmental States and the Legal Order: Towards a New Political Economy of Development and Law" ( paper presented at the Conference on Social Science in the Age of Globalization, National Institute for Advanced Study on Social Science, Fudan University, Shanghai, December 2008).

${ }^{15}$ Trubek, "Developmental States and the Legal Order", 9.

${ }^{16}$ Trubek, "Developmental States and the Legal Order", 11.

${ }^{17}$ Robert Wade, »After the Crisis: Industrial Policy and the Developmental State in LowIncome Countries«, Global Policy Vol.1, Issue 2 (May 2010): 157.

${ }^{18}$ Wade, "After the Crisis", 157.

${ }^{19}$ Wade, "After the Crisis", 158-159.

${ }^{20}$ Birdsall, Fukuyama, "The Post-Washington Consensus", 53.

${ }^{21}$ Ivan Berend, "Central and Eastern Europe in the Word Economy: Past and Prospects", Development and Finance, 1 (2011): 2

${ }^{22}$ See http://data.worldbank.org/about/country-classifications.

23 The World Bank, Worldwide Governance Indicators, available at http://info.worldbank.org/governance/wgi/index.asp 
24 Daniel Kaufman, Aart Kraay,and Massimo Mastruzzi, Governance Matters VIII: Governance Indicators for 1996-2008 (World Bank Policy Research, Working Paper no.4978, June 2009).

25 Freedom House Nations in Transit 2012: Fragile Frontier: Democracy's Growing Vulnerability in Central and Southeastern Europe, available at http://www.freedomhouse.org/report/nations-transit/nations-transit-2012.

${ }^{26}$ Freedom House Nations in Transit 2012.

${ }^{27}$ Randal Peerenboom, "The Political Economy of Rule of Law in Middle-Income Countries: A Comparison of Eastern Europe and China", UCLA Pacific Basin Law Journal 28 (20102011): 67.

${ }^{28}$ Berend, "Central and Eastern Europe in the Word Economy",1.

${ }^{29}$ Berend, "Central and Eastern Europe in the World Economy",1.

${ }^{30}$ Ha-Joon Chang, "Institutions and economic development: theory, policy and history", Journal of Institutional Economics, 7 (4) 2011: 473.

${ }^{31}$ Chang, "Institutions and economic development", 473.

32 Julio Faundez, "Rule of Law or Washington Consensus: The Evolution of the World Banks's Approach to Legal and Judicial Reform", in Amanda Perry-Kesaris, ed., Law in the Pursuit of Development (London: Routledge; 2010); Tor Krever, "The Legal Turn in Late Development Theory: The Rule of Law and the World Bank's Development Model", Harvard Journal of International Law, vol.52 (1), (Winter 2011): 302, 305.

${ }^{33}$ Chang, "Institutions and economic development", 476.

${ }^{34}$ Chang, "Institutions and economic development", 477.

${ }^{35}$ Chang, "Institutions and economic development", 484.

36 Alice H.Amsden,Jacek Kochanowicz, Lance Taylor, The Market Meets Its Match: Restructuring teh Economies of Eastern Europe (Cambridge: Harvard University Press, 1994): 119.

${ }^{37}$ A.J.G. Verheijen, "Administrative Capacity Development: A Race Against Time?", WRR Working Documents, W 107. The Hague (2000):15.

38 Francisco Cardona," Introducing the Rule of Law in Civil Service and Public Administration Reform: The Case of the EU Eastern Enlargement" ( Paper presented at conference on »Reforming Public Adminisrtation through Functional Reviews«, Sarajevo, 5 May 2004): 7.

39 SIGMA- Support for Improvement in Governance and Management in Accession Countries. SIGMA is an OECD unit principally sponsored by the European Union. 
Jerusalem Papers in Regulation \& Governance

${ }^{40}$ Jan-Hinrik Meyer Sahling,"»The Durability of EU Civil Service Policy in Central and Eastern Europe after Accession", Governance 24 (2) (2011): 240.

${ }^{41}$ Christopher Pollitt, Geert Bouckaert, Public Management Reform: A Comparative Analysis (Oxford: Oxford University Press, 2000): 59.

${ }^{42}$ The NPM usually refers to a broad set of programmes that sought to introduce more managerial discretion, competition and flexibility into the "old" Weberian model of public administration.

${ }^{43}$ Conor O'Dwyer, "Civilizing the State Bureaucracy: The Unfulfilled Promise of Public Administration Refom in Poland, Slovakia, and the Czech Republic (1990-2000)", (Institute of Slavic, East European, and Eurasian Studies, Berkeley Program in Soviet and Post-Soviet Studies, University of Berkeley, California, Year 2002, Paper 2002/01):31.

${ }^{44}$ A.J.G. Verheijen, "Public Administration in Post-Communist States", in B.Guy Peters \& Jon Pierre, (eds.), Handbook of Public Administration ( London; Sage Publications, 2003): 491.

${ }^{45}$ Verheijen, "Public Administration in Post-Communist States", 491.

${ }^{46}$ The World Bank, "EU-8 Administrative Capacity in the New Member States: The Limits of Innovation?," (Study. Poverty Reduction and Economic Management unit Europe and Central Asia. Report Number: 36930-GLB, 2006), 50.

${ }^{47}$ World Bank, "EU-8 Administrative Capacity," 10.

${ }^{48}$ Adam Michnik, "The Polish witch-hunt", The New York Review of Books, June 28, 2007.

${ }^{49}$ Meyer Sahling, "The Durability of EU Civil Service Policy in Central and Eastern Europe after Accession", 231.

${ }^{50}$ Meyer Sahling, "The Durability of EU Civil Service Policy in Central and Eastern Europe after Accession", 243.

${ }^{51}$ OECD Public Governance Reviews.Slovenia. Review of the Public Sector Salary System, September (2011).

52 Jan-Hinrik Meyer Sahling, Tim Veen, "Governing the Post-Comunist State: Government Alteration and Senior Civil Service Politicization in Central and Eastern Europe", East European Politics, vol.8 (1) (2012): 10-11.

${ }^{53}$ Meyer Sahling, "The Durability of EU Civil Service Policy in Central and Eastern Europe after Accession", 247.

${ }^{54}$ Meyer Sahling, "The Durability of EU Civil Service Policy in Central and Eastern Europe after Accession", 242. 
${ }^{55}$ Meyer Sahling, "The Durability of EU Civil Service Policy in Central and Eastern Europe after Accession", 248.

${ }^{56}$ Verheijen, "Public Administration in Post-Communist States", 496.

${ }^{57}$ Jan-Hinrik Meyer-Sahling, "Civil Service Reform in Post-Communist Europe: The Bumpy Road to Depoliticisation, " West European Politics 27:1 (2004):98.

${ }^{58}$ Birdsall, Fukuyama, "The Post-Washingtom Consensus",51.

${ }^{59}$ Kennedy, "Law and Development Economics", 27.

${ }^{60}$ See example of civil service reforms.

${ }^{61}$ Kennedy,"Law and Development", 29.

${ }^{62}$ Kennedy," Law and Development",30.

${ }^{63}$ Kennedy," Law and Development", 30.

${ }^{64}$ Agnes Batory,"Why do anti-corruption laws fail in Central Eastern Europe? A Target compliance perspective", Regulation \& Governance 6 (2012): 66; Antoaneta Dimitrova, Institutionalization of Imported Rules in the European Union's New Member States: Bringing Politics Back in the Research Agenda, EUI Working Papers, RSCAS 2007/37, EUI, Florence: 11-12.

${ }^{65}$ Bojan Bugaric, "The Europeanization of National Administrations in Central and Eastern Europe: Creating Formal Structures without Substance?", in Wojciech Sadurski, Jacques Ziller, and Karoline Zurek, eds., Apres Enlargement: Legal and Political Responses in Central and Eastern Europe (Florence: European University Institute, Robert Schuman Centre for Advances Studies, 2006).

${ }^{66}$ David Trubek , "The Political Economy of the Rule of Law: The Challenge of the New Developmental State", Hague Journal on the Rule of Law 1 (2009):28-32.

${ }^{67}$ Kennedy, "Law and Development", 1-2.

68 Dorothee Bohle, Bela Greskovits, "Neoliberalism, Embedded Neoliberalismand Neocorporativism: Towards Transnational Capitalism in Central-Eastern Europe", West European Politics, vol.30 (3), 2007, 443.

${ }^{69}$ Dorothee Bohle, Bele Greskovits, "Capitalist Diversity in Eastern Europe", Economic sociology, Vol.8, No.2 (March 2007): 5-

${ }^{70}$ Adam Torok, "Industrial Policy in the new Member Countries of the European Union: A Survey of Patterns and Initiatives Since 1990", Journal of Industry, Competition and Trade 7 (3) (2007) : 256.

${ }^{71}$ G.W. Kolodko, A Two-thirds Rate of Success. Polish Transformation and Economic Development, UNU/WIDER Research paper no. 2009/14, 2. 
${ }^{72}$ Kolodko, "A Two-thirds Rate of Success", 2.

73 Joseph E.Stiglitz, Globalization and Its Discontent (New York: W.W.Norton and Company, 2004): 181.

${ }^{74}$ Stiglitz, Globalization and Its Discontent, 181.

${ }^{75}$ Tadeusz Kowalik, From Solidarity to Sellout: The Restoration of Capitalism in Poland (Monthly Review Press, 2012).

76 Grzegorz W.Kolodko, From Shock to Therapy. Political Economy of Possocialist Transition (Oxford: Oxford University Press, 2000).

${ }^{77}$ Grzegorz W. Kolodko, Truth, Errors, and Lies: Politics and Economics in a Volatile World (New York: Columbia University Press, 2011).

${ }^{78}$ Grzegorz W. Kolodko, e-mail message to author, July, 20, 2012.

${ }^{79}$ Birdsall, Fukuyama, "The Post-Washingtom Consensus", 51,

${ }^{80}$ Francis Fukuyama, Do Institutions Really Matter, January 23, 2012, Francis Fukuyama American Interest blog, http:// blogs.the-american-interest-com/fukuyama

${ }^{81}$ Rainer .Kattel, Erik S.Reinert, Margit Suurna, Industrial Restructuring and Innovation Policy in Central and Eastern Europe since 1990, Working Papers in Technology Governance and Economic Dynamics no.23, May 2009, 2.

${ }^{82}$ Torok, "Industrial Policy in the new Member Countries of the European Union", 255.

83 Neil Nugent, The Government and Politics of the European Union, 7th Edition (Basingstoke: Palgrave MacMillan, 2010): 339.

${ }^{84}$ Nugent, The Government and Politics of the European Union, 339.

${ }^{85}$ Kattel,Reinert, Suurna, "Industrial Restructuring and Innovation Policy in Central and Eastern Europe since 1990",35.

${ }^{86}$ Kattel,Reinert, Suurna, "Industrial Restructuring and Innovation Policy in Central and Eastern Europe since 1990",2-3.

${ }^{87}$ Kattel,Reinert, Suurna, "Industrial Restructuring and Innovation Policy in Central and Eastern Europe since 1990", 23.

${ }^{88}$ Kattel,Reinert, Suurna, "Industrial Restructuring and Innovation Policy in Central and Eastern Europe since 1990", 29.

${ }^{89}$ Christopher Pollitt,Colin Talbot, eds., Unbundled Government: A critical analysis of the global trend to agencies, quangos and contractualsation (London, New York: Routledge, 2004); Christopher Pollitt, Colin Talbot, Janice Caulfield, Amanda Smullen, Agencies: How Governments do Things Through Semi-Autonomous Organizations (Basingstoke, Hampshire: Palgrave Macmillan, 2004). 
Jerusalem Papers in Regulation \& Governance

${ }^{90}$ Kattel,Reinert, Suurna, "Industrial Restructuring and Innovation Policy in Central and Eastern Europe since 1990", 25.

${ }^{91}$ Jacy Meyer, "Central and Eastern Europe Lag in Innovation", The New York Times, May $22,2011$.

${ }^{92}$ Trubek, "Developmental States and the Legal Order", 12.

${ }^{93}$ Trubek, "Developmental States and the Legal Order", 10.

${ }^{94}$ On the importance of "regulatory informalism" in East Easia for post-communist countries, see Tom Ginsburg, "East Asian Regulatory Informalism: Implications for Post Communist Countries", in Denis Galligan, Marina Kurkchiyan, eds., Law and Informal Practices: The Post-Communist Experience (Oxford: Oxford University Press, 2003).

${ }^{95}$ Trubek, "Developmental States and the Legal Order"; 9.

${ }^{96}$ Freedom House Nations in Transit 2012.

${ }^{97}$ Stiglitz, Globalization and Its Discontent, 180-182.

${ }^{98}$ Roberto Mangabeira Unger, What Should Legal Analysis Become? (London, New York: Verso, 1996):7.

${ }^{99}$ Peter A.Hall, David Soskice, eds., Varieties of Capitalism: The Institutional Foundations of Comparative Advantage (Oxford:Oxford University Press, 2001).

${ }^{100}$ Gunther Teubner, "Legal Irritants: Good Faith in British Law or How Unifying Law Ends Up in New Divergencies", Modern Law Review 61/1 (1998): 12.

${ }^{101}$ Teubner, "Legal Irritants", 12.

${ }^{102}$ Batory, "Why do anti-corruption laws fail in Central Eastern Europe?",79.

${ }^{103}$ Batory, "Why do anti-corruption laws fail in Central Eastern Europe?", 78.

104 Dani Rodrik, Industrial Policy fot the Twenty-First Century, available at www.ksg.harvard.edu/rodrik/

${ }^{105}$ Birdsall, Fukuyama, "The Post-Washingtom Consensus",50.

${ }^{106}$ Birdsall, Fukuyama, "The Post-Washingtom Consensus",51.

${ }^{107}$ Alina Mungiu-Pippidi, Becoming Denmark: Understanding Good Governance Historical Achievers, book chapter The Development of Good Governance, available at http://www.againstcorruption.eu/uploads/norad/Becoming-Denmark-Historical-LessonsLearned.pdf.

${ }^{108}$ Peerenboom, "The Political Economy of Rule of Law in Middle-Income Countries", 7071.

109 Dani Rodrik, "Second-Best Institutions", American Economic Review: Papers \& Proceedings, 98:2 (2008). 
Jerusalem Papers in Regulation \& Governance

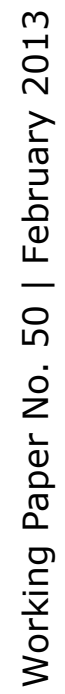

${ }^{110}$ Stephan Haggard, Andrew MacIntyre, Lyidia Tiede, "The Rule of Law and Economic Development", Annual Review of Political Science, 11 (2008): 233.

${ }^{111}$ Martin Krygier, "The Rule of Law and the "The Three Integrations", Hague Journal on the Rule of Law, 1 (2009): 24.

${ }^{112}$ Francis Fukuyama, "Transitions to the Rule of Law", Journal of Democracy, 21/1 (2010): 41. 